\title{
An Unusual Hemoglobin Anomaly and Its Relation to $\alpha$-Thalassemia and Hemoglobin-H Disease
}

\author{
G. D. Efremov, Ruth N. Wrightstone, T. H. J. Huisman, W. A. Schroeder, \\ Carol Hyman, Jorge Ortega, and Kenneth Williams
}

From the Laboratory of Protein Chemistry, Medical College of Georgia, Augusta, Georgia 30902; the Division of Chemistry and Chemical Engineering, California Institute of Technology, Pasadena, California 91109; the Childrens Hospital of Los Angeles, Los Angeles, California 90054; and the Department of Pediatrics, University of Southern California School of Medicine, Los Angeles, California 90033

A в S T R A C T A Chinese family with hemoglobin $\mathrm{H}$ in the propositus has been reinvestigated. Although the original propositus is now deceased, a sister has the same hematological manifestations. Her hemoglobin, like that of the deceased sister, contains hemoglobins $\mathrm{A}, \mathrm{H}$, and Bart's. In addition, however, two minor components have been detected. These minor components appear to have abnormal $\alpha$-chains and are also present in the maternal grandmother, the mother, a maternal aunt, and three other siblings but only in about one-tenth the amount. One of the minor components may be the same as Hb-Thai (25). The father has the characteristics of classical $\alpha$-thalassemia. These results are discussed in relation to current concepts of $\alpha$-thalassemia as they relate to "silent" and "classical" $\alpha$-thalassemia and to possible multiple $\alpha$-chain loci.

\section{INTRODUCTION}

Since hemoglobin $\mathrm{H}$ (or $\beta_{4}$ ) was detected independently by Rigas, Koler, and Osgood (1) and by Gouttas, Fessas, Tsevrenis, and Xefteri (2), many reports of its occurrence have been published. Among these reports is one of a Chinese family $(3,4)$ in which the propositus, a girl, had $\mathrm{Hb}-\mathrm{H}$ disease as manifested by the presence of $\mathrm{Hb}-\mathrm{H}$ and $\mathrm{Hb}-\mathrm{Bart}$ 's (or $\gamma_{4}$ ). These hemoglobins were characterized by chemical studies (5). Observations on family members were consistent with the usual finding in relatives of patients with $\mathrm{Hb}-\mathrm{H}$ disease, namely, that one parent is apparently normal whereas the other has a thalassemia trait (see 6-9 for summaries and references). In retrospect, the manifestation of

Received for publication 19 January 1971 and revised form 8 March 1971.
$\mathrm{Hb}-\mathrm{H}$ disease in this family has characteristics which make it unusual among reported occurrences of $\mathrm{Hb}-\mathrm{H}$ disease. The propositus had about $15 \%$ of $\mathrm{Hb}-\mathrm{H}$ and 5 $10 \%$ of Hb-Bart's (5). A significant fact is the presence of an appreciable amount of $\mathrm{Hb}$-Bart's. The girl, now deceased, was about $4 \mathrm{yr}$ old at the time of the study and would normally have reached hematological adulthood. However, in most reported instances, $\mathrm{Hb}-\mathrm{Bart}$ 's either does not accompany $\mathrm{Hb}-\mathrm{H}$ (for example 1,5 ) or is present only in traces in the adult. Recently, there has been an opportunity to reinvestigate this Chinese family. Since the original investigations, two additional siblings of the propositus have been born. In one of these, only a few per cent of $\mathrm{Hb}$-Bart's was present in the cord blood but in the youngest (S. T.) the large amount of $\mathrm{Hb}$-Bart's suggested that she, like the propositus, had $\mathrm{Hb}-\mathrm{H}$ disease. This reinvestigation has detected an anomaly in this family that may be important in understanding $\mathrm{Hb}-\mathrm{H}$ disease and $\alpha$-thalassemia.

\section{METHODS}

Blood samples were obtained from the new propositus S.T. and from other family members (Table I and Fig. 1). The original propositus, sister $\mathrm{P}$. T., described in the previous studies (3-5) had died at the age of $6 \mathrm{yr}$. On four occasions, $10-50 \mathrm{ml}$ of blood was collected from S. T. in acid-citrate dextrose solution and transported in ice by air from Los Angeles to Augusta; experiments usually started within 24 $\mathrm{hr}$ after the blood was collected. Smaller samples $(10 \mathrm{ml})$ were collected in EDTA from the other members of the family. Hematological data were obtained with freshly collected material by standard procedures (10).

Preparation of hemoglobin solution. Red cells were washed four times with $0.9 \mathrm{~g}$ per $100 \mathrm{ml} \mathrm{NaCl}$ solution and hemolyzed with an equal volume of distilled water and 0.1 vol of carbon tetrachloride for $10 \mathrm{~min}$ at $4^{\circ} \mathrm{C}$. Red cell 
TABLE I

Hematological Data

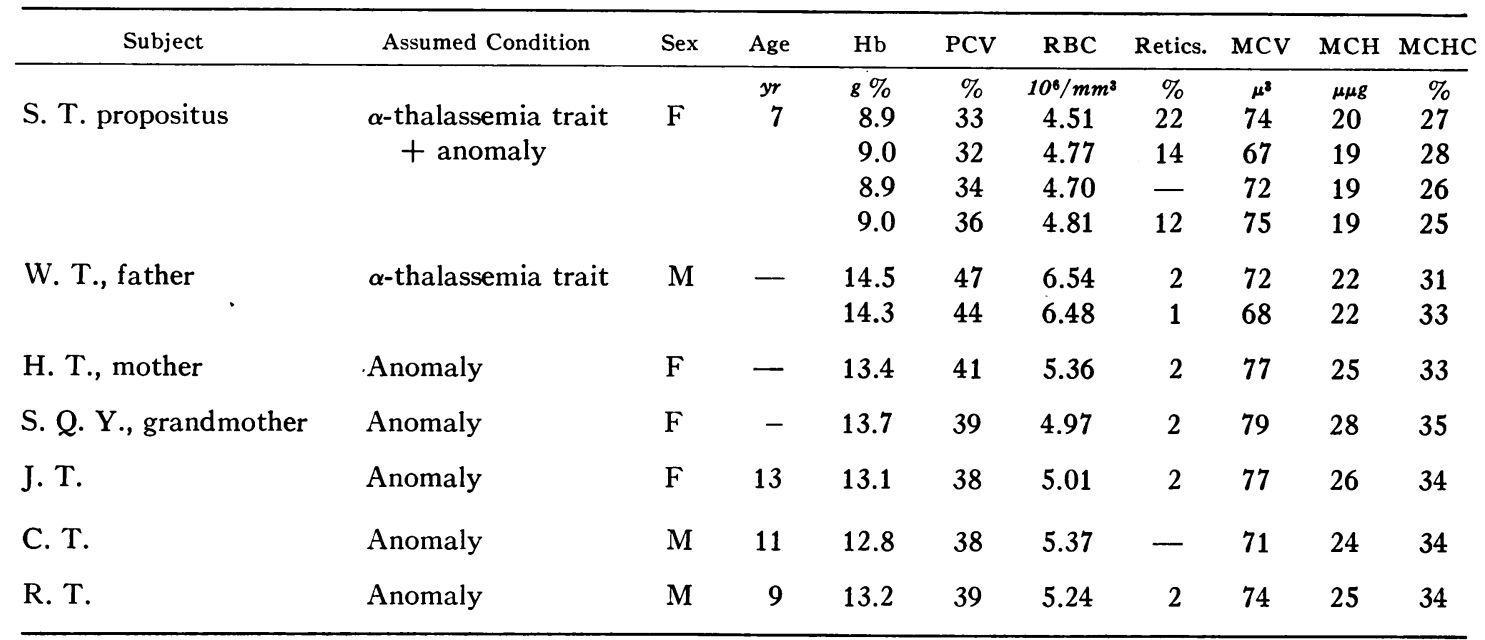

debris was removed by centrifugation at $10,000 \mathrm{rpm}$ and $4^{\circ} \mathrm{C}$ for $10 \mathrm{~min}$ in a Sorvall refrigerated centrifuge (Ivan Sorvall, Inc., Norwalk, Conn.). Time of preparation of hemolysates usually did not exceed $60 \mathrm{~min}$.

The heat stability of the hemoglobin in hemolysates was tested by a slight modification of the method of Grimes, Meisler, and Dacie (11). CO-hemoglobin (final concentration $150 \mathrm{mg}$ per $100 \mathrm{ml}$ ) was incubated in $0.1 \mathrm{M}$ sodium phosphate buffer, $\mathrm{pH} 7.4$, at $55^{\circ}-56^{\circ} \mathrm{C}$ for $5,10,15,20,30$, 40 , and $50 \mathrm{~min}$. After each solution had been cooled in ice for $5 \mathrm{~min}$ and centrifuged, the absorbancy of the supernatant was determined at $540 \mathrm{~m} \mu$ in $1 \mathrm{~cm}$ cuvettes with a Zeiss spectrophotometer.

Starch gel electrophoresis of hemoglobin in hemolysates and of isolated hemoglobin fractions was made at $\mathrm{pH} 9.0$ according to a previously described procedure (12). The gels were stained with $o$-dianisidine and with Buffalo black (Allied Chemical Corp., Morristown, N. J.).

Chromatographic procedures for hemoglobins. The separation and isolation of hemoglobin components were carried out by means of DEAE-Sephadex chromatographic techniques that have been described in detail by Huisman and Dozy (13) and Dozy, Kleihauer, and Huisman (14). Small changes which had to be introduced in the molarity and the $\mathrm{pH}$ of the Tris- $\mathrm{HCl}$ developers will be given in detail when the chromatographic experiments are described. After chromatographic fractions that contained a desired hemoglobin had been pooled, the solution was concentrated on a (small) column of CM-Sephadex by a procedure previously described (15). In some fractions, the percentage of $\mathrm{Hb}-\mathrm{F}$ was determined by a new technique (15).

Procedures for the separation of polypeptide chains. Globin from isolated hemoglobin components was prepared by the method of Anson and Mirsky (16). For analytical purposes, polypeptide chains were separated by a slight modification of the electrophoretic procedure of Chernoff and Pettit (17); the 0.075 м sodium veronal- $\mathrm{HCl}$ buffer, $\mathrm{pH}$ 8.6, which was used, was $8 \mathrm{M}$ in urea for the preparation of the gels and $6 \mathrm{~m}$ in urea in buffer vessels. Preparatively, the chains were separated chromatographically on a column $(2 \times 10 \mathrm{~cm})$ of $\mathrm{CM}$-cellulose according to the technique of Clegg, Naughton, and Weatherall $(18,19)$. The CM-cellu- lose (microgranular CM-52, preswollen, with a capacity of $1.0 \mathrm{mEq} / \mathrm{g}$ dry, H. Reeve Angel, Clifton, N. J.) was equilibrated with developer A (0.005 $\mathrm{M}$ sodium phosphate, $\mathrm{pH}$ $6.6 ; 0.05 \mathrm{M} \beta$-mercaptoethanol; $8 \mathrm{~m}$ urea). For chromatographic development, the initial $100 \mathrm{ml}$ of developer A was followed by a gradient between $450 \mathrm{ml}$ developer $\mathrm{A}$ and $450 \mathrm{ml}$ developer $\mathrm{B}$ (composition as that of developer $\mathrm{A}$, but $0.04 \mathrm{M}$ in sodium phosphate). Urea and other small molecules were removed from selected zones of the chromatogram by passage through a $2.0 \times 40 \mathrm{~cm}$ column of Sephadex G-25 (coarse) with $0.5 \%$ formic acid as developer. The protein was recovered by lyophilization.

Amino acid analyses. Isolated protein zones were hydrolyzed in $6 \mathrm{~N} \mathrm{HCl}$ at $110^{\circ} \mathrm{C}$ under reduced pressure for 24 or $72 \mathrm{hr}$. The amino acid composition of the hydrolysates was determined with a Beckman-Spinco Model 120B automatic amino acid analyzer which was equipped with long. path cells $(20)$.

\section{RESULTS}

The new propositus. S. T. is a slender girl who at the age of seven is in the 73rd percentile for height and the 37th percentile for weight. She has not had any serious infectious illnesses. Her general health is ex-

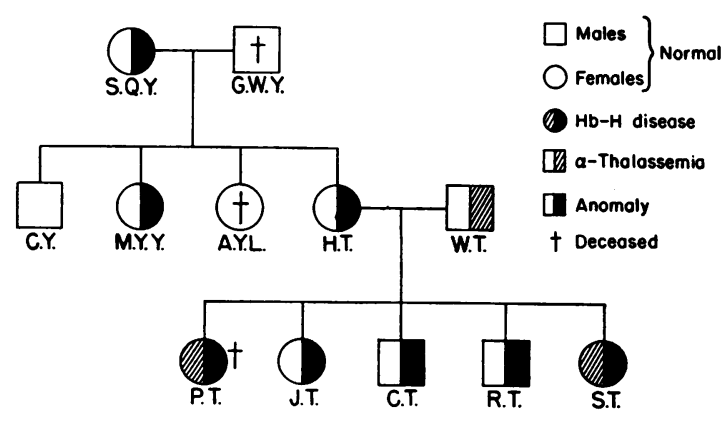

Figure 1 Pedigree of family $T$. 


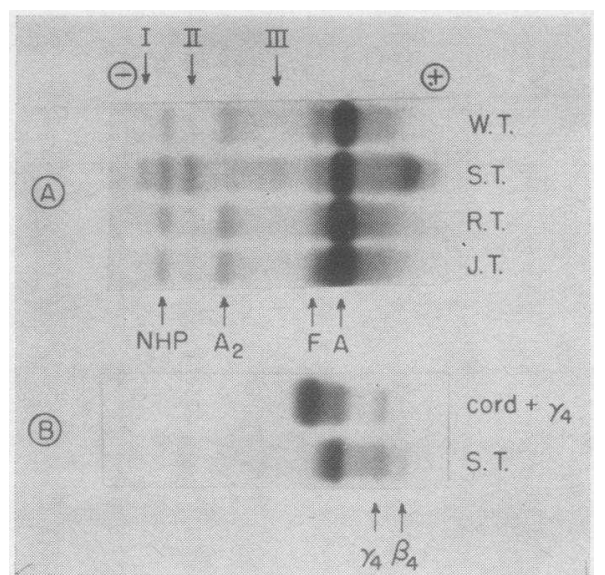

Figure 2 Starch gel electrophoresis at $\mathrm{pH} 9.0$ and $4^{\circ} \mathrm{C}$ of hemoglobin from propositus S. T., father W. T., sister J. T., and brother R. T. A. Buffalo black stain. B. o-dianisidine stain. (Because the hemolysate from $\mathrm{S}$. T. that was used for the gel in $2 \mathrm{~B}$ was about 10 days old, most of the $\mathrm{Hb}-\mathrm{H}$ has been lost.)

cellent despite the chronic mild anemia. She has not been transfused. Her liver is not palpable and spleen is 4-5 $\mathrm{cm}$ below the costal margin.

Electrophoretic observations. Fig. 2 illustrates the results of starch gel electrophoresis of hemolysates from S. T., her father W. T., and the siblings R. T. and J. T. In addition to the anticipated rapidly moving hemoglobins with mobilities similar to $\mathrm{Hb}-\mathrm{H}$ and $\mathrm{Hb}-\mathrm{Bart}$ 's, S. T.'s hemolysate has three rather slowly moving components that have been labeled I, II, and III. The amount of $\mathrm{Hb}-\mathrm{A}_{2}$ is much below normal. The electrophoretic pattern of the hemolysate from father W. T., who is considered to be an $\alpha$-thalassemia heterozygote $(3,4)$, is essentially normal. Slowly moving I and II components were not detected in W. T., but minute amounts were found in hemolysates from S. Q. Y., M. Y. Y., H. T., J. T., C. T., and R. T. (Fig. 1). In Fig. 2, data from R. T. and J. T. are given as examples. These two hemoglobin components were clearly visible on visual inspection but did not photograph well. We may conclude that the propositus and probably also her deceased sister inherited both the presumed $\alpha$-thalassemia of the father and the unknown condition of the mother. This anomaly is also inherited by S. T.'s siblings. Although components I and II are minute in amount, they were readily detected by starch gel electrophoresis in the affected relatives of S. T. However, they have not been detected in C. Y. nor in many thousands of normal individuals who have been studied by this technique in Augusta. The presence of components I and II is the presenting evidence for the anomaly. These components have also been detected in an unrelated Chinese family in Georgia in amounts com- parable to those in carriers in family $\mathrm{T}$. In S. T., in whom $\alpha$-thalassemia is presumed to be present also, there is a five- to tenfold increase in components $I$ and II. The occurrence of fraction III is primarily dependent on the age of the red cell hemolysate; this component was virtually absent in the most freshly prepared hemolysate.

Hematological studies. Hematological data on the seven members of the family are presented in Table I. S. T.'s blood smear was like that of her deceased sister P. T. (3). The cells were microcytic and hypochromic with anisocytosis, poikilocytosis, basophilic stippling, and polychromasia. Inclusion bodies were formed on incubation with brilliant cresyl blue. S. T.'s hematological data are typical of the microcytic hypochromic anemia with reticulocytosis that is present in patients with $\mathrm{Hb}-\mathrm{H}$ disease (6-9). In the father $\mathrm{W}$. T., these observations agree with older studies $(3,4)$ and with the typical characteristics of $\alpha$-thalassemia trait as summarized by Weatherall (21). The grandmother, mother, and three siblings who are considered to have the anomaly, although not anemic, have some morphologic abnormalities of their red cells. These include slight microcytosis, hypochromia, polychromasia, anisocytosis, poikilocytosis with occasional ovalocytes and target cells, and rare basophilic stippling. On some examinations, the morphologic changes of the erythrocytes are sufficiently slight so that they are missed in routine examinations.

Heat stability. The presence of heat-unstable hemoglobin components in the hemolysate of propositus S. T. is illustrated in Fig. 3. About $17 \%$ of hemoglobin (presumably $\mathrm{Hb}-\mathrm{H}$ and $\mathrm{Hb}$-Bart's) is precipitated upon heating for $30 \mathrm{~min}$ at $55^{\circ}-56^{\circ} \mathrm{C}$ whereas only $3-4 \%$ of hemoglobin is precipitated during a similar treatment from hemolysates of a normal control (T. H. J. H.) and of sibling $\mathrm{C} . \mathrm{T}$.

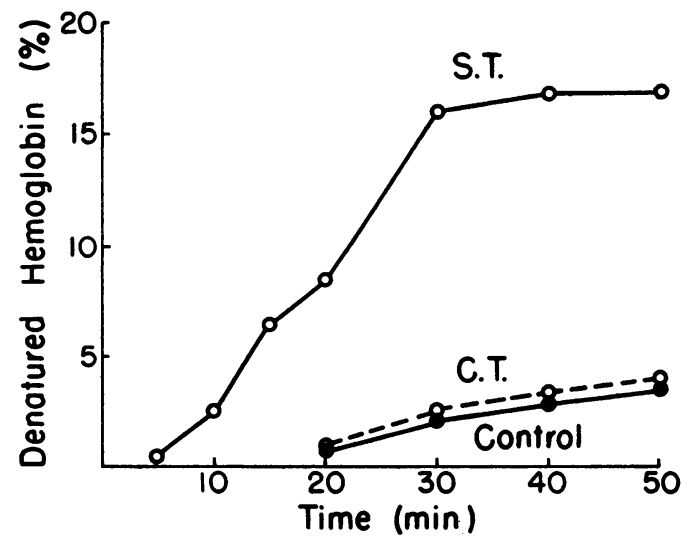

FIgURE 3 Heat stability of hemoglobin from propositus S. T., her brother C. T., and a normal control. 
Chromatographic analyses. The DEAE-Sephadex chromatogram of $60 \mathrm{mg}$ of hemoglobin from hemolysate of S. T. also showed the presence of several minor hemoglobin components (Fig. 4). Starch gel electrophoresis identified the first as a mixture of $\mathrm{Hb}-\mathrm{A}_{2}$ and component I, and the second as component II with some component III. Zone IV contained $\mathrm{Hb}-\mathrm{H}$ and Zone $\mathrm{V}$ consisted mainly of $\mathrm{Hb}$-Bart's.

Chromatographic identification of the minor components I and II in hemolysates from heterozygotes for the anomaly required the application of larger amounts of hemoglobin to the column. Fig. 5 illustrates the first part of a chromatogram of $120 \mathrm{mg}$ of hemoglobin from hemolysate of subject $\mathrm{R}$. T. The two minor fractions, one of which eluted ahead of $\mathrm{Hb}-\mathrm{A}_{2}$ and the other behind $\mathrm{Hb}-\mathrm{A}_{2}$, had electrophoretic mobilities identical with components I and II in the hemolysate of propositus S. T.

Table II summarizes the relative amounts of the various minor components. The analyses on two separate samples from subject $\mathrm{S}$. $\mathrm{T}$. indicate the presence of $0.5 \%$ of component I, $3.5 \%$ of component II, and somewhat variable amounts of the zones IV and $\mathrm{V}$ which contain primarily $\mathrm{Hb}-\mathrm{H}\left(\beta_{4}\right)$ and $\mathrm{Hb}-\mathrm{Bart}$ 's $\left(\gamma_{4}\right)$, respectively. The level of $\mathrm{Hb}-\mathrm{A}_{2}$ at $0.6-0.7 \%$ is only one-fourth of the value found in normal individuals. The levels of components $\mathrm{I}$ and II in the siblings $\mathrm{J}$. T. and R. T. were about 0.1 and $0.2 \%$ respectively. The $\mathrm{Hb}-\mathrm{A}_{2}$ levels and the percentages of $\mathrm{Hb}-\mathrm{F}$ in the parents fell within the normal range. Separation of components I and II and $\mathrm{Hb}-\mathrm{A}_{2}$ in hemolysates from the mother and grandmother were incomplete.

Isolation of components $I$ and II in larger quantities. About $1 \mathrm{~g}$ of hemoglobin from hemolysate of the propositus was chromatographed on a $2.5 \times 40 \mathrm{~cm}$ column of DEAE-Sephadex at $4^{\circ} \mathrm{C}$. The column was equilibrated with an $0.04 \mathrm{M}$ Tris- $\mathrm{HCl}$ developer, $\mathrm{pH} 7.8$; the

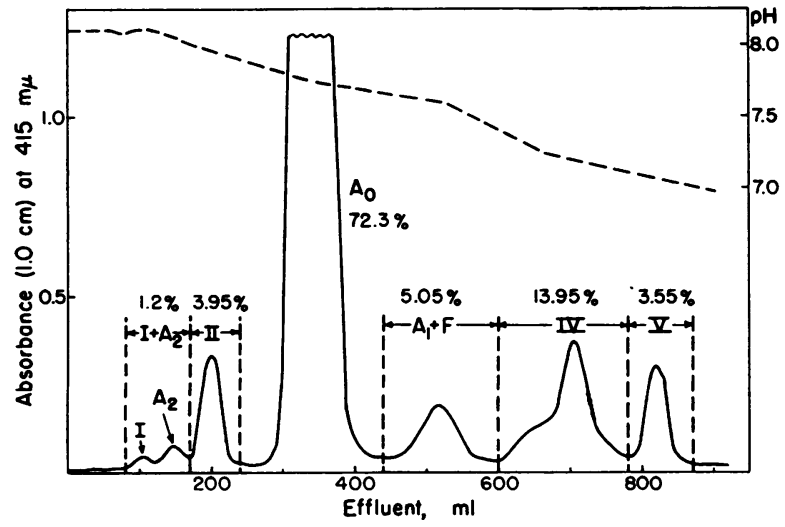

FIgURE 4 DEAE-Sephadex chromatography of $60 \mathrm{mg}$ of hemoglobin from propositus S. T. For details see text.

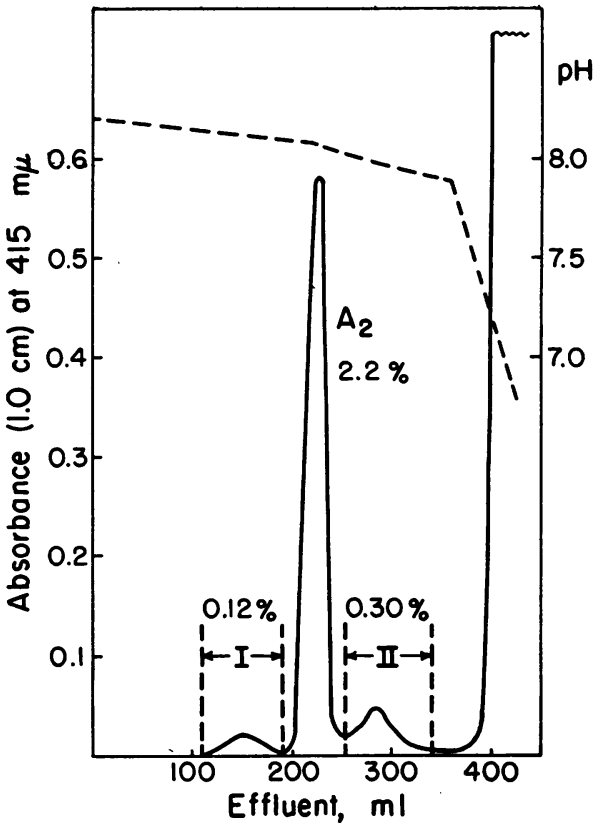

FiguRE 5 DEAE-Sephadex chromatography of $120 \mathrm{mg}$ of hemoglobin from subject R. T. For details see text.

same developer was used for the elution of the various hemoglobin fractions. Fig. 6 presents a drawing of the column after about $800 \mathrm{ml}$ of developer with a flow rate of approximately $50 \mathrm{ml} / \mathrm{hr}$ had passed through. Sections of DEAE-Sephadex with the various hemoglobin components (zones A, B, C, D, and $\mathrm{E}$ as indicated in Fig. 6) were removed from the tube, and the hemoglobin was eluted from each section individually with $0.2 \mathrm{M}$ Tris- $\mathrm{HCl}$ developer, $\mathrm{pH}$ 7.2.

Electrophoretic properties of some of these isolated fractions are also presented in Fig. 6. Zone $\mathrm{E}$ contained a mixture of $\mathrm{Hb}-$ Bart's, $\mathrm{Hb}-\mathrm{A}_{1}, \mathrm{Hb}-\mathrm{F}$, and some $\mathrm{Hb}-\mathrm{H}$, and zone $\mathrm{D}$ contained $\mathrm{Hb}-\mathrm{A}_{0}$ only. Components II and

TABLE II

Quantitative Data from DEAE-Sephadex Chromatograms*

\begin{tabular}{lcccccc}
\hline Subject & $\begin{array}{c}\text { Zone } \\
\text { I }\end{array}$ & A2 & $\begin{array}{c}\text { Zone } \\
\text { II }\end{array}$ & A1 + F & $\begin{array}{c}\text { Zone } \\
\text { IV }\end{array}$ & $\begin{array}{c}\text { Zone } \\
\text { V }\end{array}$ \\
\hline S. T. & 0.5 & 0.7 & 3.95 & $5.05 \ddagger$ & $13.95 \S$ & $3.55 \S$ \\
& 0.4 & 0.65 & 3.4 & 3.75 & 15.7 & 5.2 \\
W. T. & 0 & 2.5 & 0 & $11.3 \ddagger$ & 0 & 0 \\
H. T. & $\|$ & 2.2 & $\|$ & $12.1 \ddagger$ & 0 & 0 \\
S. Q. Y. & $\|$ & 2.4 & $\|$ & $\|$ & $\|$ & $\|$ \\
J. T. & 0.08 & 1.6 & 0.16 & $\|$ & $\|$ & $\|$ \\
R. T. & 0.12 & 2.2 & 0.30 & $\|$ & $\|$ & $\|$ \\
\hline
\end{tabular}

* Zones as indicated in Fig. 4 and Fig. 5.

‡ The percentage of $\mathrm{Hb}-\mathrm{F}$ was determined by the method of Schroeder $\mathrm{et} \mathrm{al}$. (15). The total amount of $\mathrm{Hb}-\mathrm{F}$ in $\mathrm{S}$. T. was $2.0 \%$, in W. T. $1.1 \%$, and in H. T. $0.5 \%$.

\& Fraction IV was $\mathrm{Hb}-\mathrm{H}$ and Fraction V contained primarily Hb Bart's. $\|$ The conditions of chromatography prevented quantitation. 


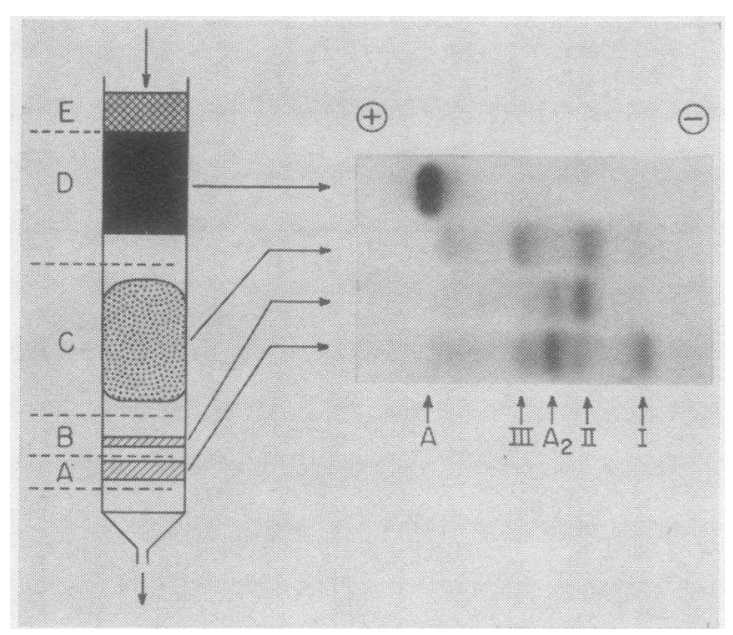

Figure 6 Drawing of the preparative DEAE-Sephadex chromatogram of approximately $1 \mathrm{~g}$ of hemoglobin from propositus S. T. Hemoglobins from four zones were studied by starch gel electrophoresis at $\mathrm{pH} 9.0$ and $4^{\circ} \mathrm{C}$; $o$-dianisidine stain. See text for details.

III comprised the most of zone $\mathrm{C}$ although detectable amounts of $\mathrm{Hb}-\mathrm{A}$ and component I were present. Although some $\mathrm{Hb}-\mathrm{A}_{2}$ was present, the main hemoglobin of the minor zone B had a mobility slightly faster than that of component II. Only zone A contained component $\mathrm{I}$, although $\mathrm{Hb}-\mathrm{A}_{2}$ was the main hemoglobin and minute amounts of $\mathrm{Hb}-\mathrm{A}$, component II and component III were also present. Because the amount of protein in zones $\mathrm{A}, \mathrm{B}$, and $\mathrm{C}$ was small, further purification was not attempted.

Some structural studies. Globins prepared from zones A, B, and $\mathrm{C}$ of the preparative chromatogram (Fig. 6) were analyzed by starch gel electrophoresis at $\mathrm{pH} 8.6$ in the presence of $8 \mathrm{M}$ urea (Fig. 7). All three globins

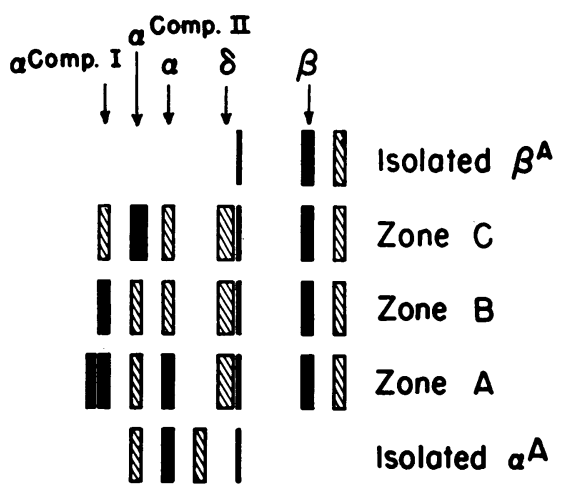

FIgURE 7 Starch gel electrophoretic separation of polypeptide chains of globin isolated from three zones of the preparative DEAE-Sephadex chromatogram of Fig. 6 . The normal $\alpha$ - and $\beta$-chains were isolated from globin of a normal control. For conditions of electrophoresis see text; Buffalo black stain. contained normal $\beta$ chains and evidently some $\delta$-chains. Of the two $\alpha$-chains in zone A, the normal $\alpha$-chain likely derives from the $\mathrm{Hb}-\mathrm{A}=$ in this zone and the abnormal $\alpha$-chain (termed the $\alpha^{\alpha}$ (wmp. I chain) from component I. The $\alpha^{\text {comp. I }}$ chain was present as two distinct zones with only slightly different electrophoretic mobilities; the mobility of one of these $\alpha^{\text {comp. I }}$ chains was identical with that of the major $\alpha$-chain of zone $B$. These observations suggest that the major hemoglobin of zone $\mathrm{B}$ is derived from component $\mathrm{I}$ of zone $\mathrm{A}$ in the same way that component III appears to be derived from component II. The mobility of the major $\alpha$-chain of zone C (the $\alpha^{\text {Comp. II }}$ chain) was intermediate between those of the $\alpha$ - and $\alpha^{\text {comp. I }}$ chains. The same type of $\alpha$-chain seems, therefore, to be present in both components (II and III) of zone C. The $\alpha^{\text {comp. II }}$ band was rather broad and the possibility that two components were present, as observed for the $\alpha^{\text {comp. I }}$ chain, must be considered (Fig. 7).

The heterogeneity of the $\alpha$-chains of the globin in zones $\mathrm{A}$ and $\mathrm{C}$ is also demonstrated by the results of the chromatography of these globins on columns of CMcellulose (Fig. 8). The amino acid composition of hydrolysates of four regions of the chromatogram of zone A and three of that of zone $C$ is shown in Table III. The amino acid compositions of zones A-1, A-2, and A-3 agree with those of the normal $\beta_{-}, \delta_{-}$, and $\alpha$-chains, respectively. Similarly, the amino acid composition of zone $\mathrm{C}-1$ is not different from that of normal $\alpha$-chain.

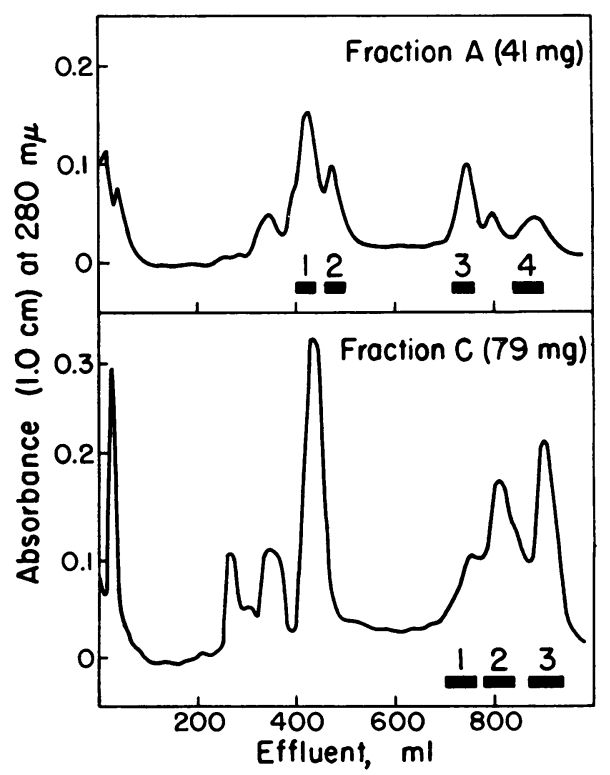

FIGURE 8 Chromatographic separation of polypeptide chains of globin isolated from zones $A$ and $C$ of the preparative DEAE-Sephadex chromatogram of 'Fig. 6. For conditions of chromatography, see text. 
TABLE III

Amino Acid Composition* of Zones Isolated from Chromatograms of Fig. 8

\begin{tabular}{|c|c|c|c|c|c|c|c|c|c|c|c|c|}
\hline \multirow{2}{*}{ Amino acid } & \multicolumn{4}{|c|}{ Zone A } & \multicolumn{5}{|c|}{ Zone $\mathrm{C}$} & \multicolumn{3}{|c|}{ Theoretical } \\
\hline & \multirow{2}{*}{$\frac{\mathrm{A}-1}{11.0}$} & \multirow{2}{*}{$\begin{array}{l}\mathrm{A}-2 \\
11.0\end{array}$} & \multirow{2}{*}{$\begin{array}{l}\mathrm{A}-3 \\
10.9\end{array}$} & \multirow{2}{*}{$\begin{array}{l}\mathrm{A}-4 \\
10.3\end{array}$} & \multirow{2}{*}{$\frac{C-1}{10.4}$} & \multicolumn{2}{|c|}{$\mathrm{C}-2$} & \multicolumn{2}{|c|}{$\mathrm{C}-3$} & \multirow{2}{*}{$\frac{\alpha}{11}$} & \multirow{2}{*}{$\begin{array}{c}\beta \\
11\end{array}$} & \multirow{2}{*}{$\frac{\delta}{11}$} \\
\hline Lysine & & & & & & 10.4 & 11.1 & 9.8 & 9.8 & & & \\
\hline Histidine & 8.4 & 7.0 & 9.8 & 9.6 & 10.4 & 9.4 & 10.3 & 9.9 & 9.3 & 10 & 9 & 7 \\
\hline Arginine & 3.8 & 4.0 & 3.3 & 4.0 & 3.2 & 4.2 & 4.3 & 4.3 & 4.6 & 3 & 3 & 4 \\
\hline Aspartic acid & 13.4 & 15.3 & 11.9 & 11.0 & 11.2 & 10.5 & 10.9 & 9.9 & 9.9 & 12 & 13 & 15 \\
\hline Threonine & 6.2 & 5.3 & 7.8 & 7.4 & 7.3 & 6.9 & 6.6 & 7.2 & 6.1 & 9 & 7 & 5 \\
\hline Serine & 6.0 & 5.9 & 8.6 & 9.2 & 8.4 & 8.1 & 6.3 & 9.0 & 6.5 & 11 & 5 & 6 \\
\hline Glutamic acid & 11.2 & 11.8 & 5.1 & 5.6 & 5.4 & 6.2 & 6.0 & 6.3 & 6.5 & 5 & 11 & 12 \\
\hline Proline & 6.9 & 6.5 & 7.2 & 7.5 & 7.3 & 7.8 & 7.9 & 8.2 & 8.6 & 7 & 7 & 6 \\
\hline Glycine & 12.6 & 13.0 & 7.9 & 7.6 & 8.0 & 6.9 & 7.6 & 7.1 & 7.0 & 7 & 13 & 13 \\
\hline Alanine & 14.3 & 14.4 & 19.5 & 20.9 & 19.4 & 20.8 & 21.2 & 20.1 & 20.0 & 21 & 15 & 15 \\
\hline Valine & 14.8 & 15.0 & 13.2 & 12.2 & 13.2 & 12.6 & 13.6 & 13.2 & 12.6 & 13 & 18 & 17 \\
\hline Methionine & 0.8 & 1.3 & 1.5 & 1.1 & 0.6 & 1.3 & 0.6 & 1.2 & - & 2 & 1 & 2 \\
\hline Leucine & 16.3 & 17.3 & 17.0 & 17.1 & 17.2 & 17.3 & 17.2 & 17.2 & 17.7 & 18 & 18 & 18 \\
\hline Tyrosine & 3.0 & 2.8 & 3.0 & 2.5 & 2.7 & 2.6 & 2.6 & 2.9 & 2.5 & 3 & 3 & 3 \\
\hline Phenylalanine & 7.2 & 8.2 & 7.3 & 7.0 & 7.1 & 7.2 & 6.6 & 7.8 & 7.1 & 7 & 8 & 8 \\
\hline Hydrolysis timeł & $24 \mathrm{~h}$ & $24 \mathrm{~h}$ & $24 \mathrm{~h}$ & $24 \mathrm{~h}$ & $24 \mathrm{~h}$ & $24 \mathrm{~h}$ & $72 \mathrm{~h}$ & $24 \mathrm{~h}$ & $72 \mathrm{~h}$ & & & \\
\hline Identity§ & $\beta$ & $\delta$ & $\alpha$ & $\alpha^{\text {Comp. I }}$ & $\alpha$ & & . II & $\alpha^{\mathrm{C}_{c}}$ & 11 & & & \\
\hline
\end{tabular}

* As number of residues per molecule of polypeptide chain.

$\ddagger$ At $110^{\circ} \mathrm{C}$ in vacuo with $6 \mathrm{~N} \mathrm{HCl}$.

$\S$ As suggested from these analyses.

The amino acid composition of zone A-4 (considered to be the $\alpha^{\text {comp. I }}$ chain) differs slightly from that of the normal $\alpha$-chain. Zones $\mathrm{C}-2$ and C-3 (both considered to be $\alpha^{\text {Comp. II }}$ chains) are similar, but perhaps not identical, in amino acid composition to zone A-4. The differences which appear to be in arginine, aspartic acid, and glutamic acid could produce the observed alterations in electrophoretic and chromatographic properties.

\section{DISCUSSION}

This reinvestigation of family $\mathrm{T}$ has shown another child, $\mathrm{S}$. T., with the same characteristics of $\mathrm{Hb}-\mathrm{H}$ disease that were seen in P. T., the deceased propositus. At the age of 4, P. T.'s hemoglobin had $15 \%$ of $\mathrm{Hb}-\mathrm{H}$ and about $5-10 \%$ of Hb-Bart's (5) ; S. T.'s hemoglobin at age 7 has much the same percentages (Table II). The expression of the condition in these siblings, therefore, appears to be comparable. In addition to these hemoglobins and to $\mathrm{Hb}-\mathrm{A}$, which were also observed in P. T., S. T.'s hemoglobin contains an abnormally small percentage of $\mathrm{Hb}-\mathrm{A}_{2}$ as well as minor components $\mathrm{I}$ and II which appear to be abnormal in the $\alpha$-chain. We assume that the same situation obtained in P. T.'s hemoglobin but was not observed because methods that have detected them in S. T. were not available or not applied. The hematological data on the father $\mathrm{W}$. T. accord with earlier determinations $(3,4)$ and with the features of $\alpha$-thalassemia (21); minor components I and II are absent. The grandmother S. Q. Y., mother H. T., and siblings J. T., C. T., and R. T. have red cell indices that differ only slightly from normal. All five, however, and a maternal aunt do contain minor components I and II in about one-tenth the amount of S. T.'s. In attempting to assess the nature of the anomaly that these possess, data from a study of the cord bloods of J. T., C. T., and R. T. is of considerable significance. As indicated by Sturgeon, Jones, Bergren, and Schroeder (4), $\mathrm{Hb}-$ Bart's was qualitatively present in J. T.'s cord hemoglobin and amounted to $4 \%$ in C. T.'s cord blood. It was also present in R. T.'s cord blood (W. R. Bergren, personal communication). However, $\mathrm{Hb}-\mathrm{Bart}$ 's comprised about $40 \%$ of the cord hemoglobin of S. T. (R. T. Jones, personal communication). The presence of Hb-Bart's at birth and during the neonatal period is generally considered to be indicative of an $\alpha$-thalassemia heterozygote, and on this basis, the three children, and by inference their mother, grandmother, and maternal aunt should be considered $\alpha$-thalassemia heterozygotes. If this be so, the type of $\alpha$-thalassemia must differ from that of the father.

The genetic basis for $\mathrm{Hb}-\mathrm{H}$ disease has been a subject for speculation since its discovery because $\mathrm{Hb}-\mathrm{H}$ usually is not demonstrable in the blood of parents with affected offspring. Among the numerous published reports of $\mathrm{Hb}-\mathrm{H}$ disease, many lack significance in any at- 
tempt to explain $\mathrm{Hb}-\mathrm{H}$ disease because family studies were not or could not be made, because $\mathrm{Hb}-\mathrm{H}$ was not quantitatively determined, or because $\mathrm{Hb}$-Bart's was not mentioned and, therefore, may or may not have been present. In many discussions of $\mathrm{Hb}-\mathrm{H}$ disease, it is stated or implied that $\mathrm{Hb}-\mathrm{Bart}$ 's is characteristically present. However, $\mathrm{Hb}-\mathrm{H}$ without $\mathrm{Hb}-\mathrm{Bart}$ 's appears to be more likely. For example, Hb-Bart's is present in family $T$. but not (5) in individuals of the family described by Rigas et al. (1). Likewise, Necheles, Cates, Sheehan, and Meyer (22) report Hb-Bart's in only one of three cases and Kattamis and Lehmann (23) in three of nine. The presence of $\mathrm{Hb}-$ Bart's in family $\mathrm{T}$. sets it apart from the majority of cases: the presence of minor components ( $\mathrm{I}$ and II) is an additional difference. Because many reports list $\mathrm{Hb}-\mathrm{H}$ or $\mathrm{Hb}-\mathrm{Bart}$ 's at levels of $5-10 \%$, it would be surprising if minor component II which occurs at a level of $3-4 \%$ in S. T. would have been overlooked unless it was erroneously identified as $\mathrm{Hb}-\mathrm{A}_{2}$. If these components have been overlooked by others, the cause may lie in the use of old cells or old hemolysates in which there may have been loss of these somewhat unstable hemoglobins or change in their mobility. Components I and II probably have been observed by Wasi et al. (24) (see their Fig. 2) who indicate that their positions approximate those of $\mathrm{Hb}$ Gower 1 and Gower-2. One of them may be equivalent to what has been termed $\mathrm{Hb}$-Thai which is believed to have an abnormal $\alpha$-chain (25). Our chemical analyses exclude the possibility that components I and II are identical with the Gower components or with $\delta_{4}$ which has been reported as a minor component in some cases of $\mathrm{Hb}-\mathrm{H}$ disease (26).

There is no obvious relationship of the anomaly in family T. to $\alpha$-thalassemia or to common expressions of $\mathrm{Hb}-\mathrm{H}$ disease. Is this anomaly an overt and hitherto unobserved expression of the "silent" $\alpha$-thalassemia gene that in conjunction with a "classical" $\alpha$-thalassemia gene has been suggested as the genetic basis of $\mathrm{Hb}-\mathrm{H}$ disease? The concept of a "silent" or recessive gene was proposed by Sturgeon et al. (4) and has been developed by Wasi (25) and Wasi, Na-Nakorn, and $\mathrm{Su}$ ingdumrong (27). If the anomaly in family $\mathrm{T}$. is equivalent to "silent" $\alpha$-thalassemia, another aspect must be added to $\alpha$-thalassemia because thalassemias are not believed to involve abnormalities in sequence of either $\alpha$ or $\beta$-chains: however, components I and II appear to contain abnormal $\alpha$-chains. Furthermore, it is also necessary to rethink those speculations that consider $\mathrm{Hb}-\mathrm{H}$ disease to result from a combination of "classical" and "silent" $\alpha$-thalassemia genes. Future work with presumed carriers of "silent" $\alpha$-thalassemia must determine whether or not their hemoglobin contains components I and II.
Koler and Rigas (28) suggested two independently segregating $\alpha$-loci as an explanation of the genetics of $\mathrm{Hb}-\mathrm{H}$. On this basis, Lehmann and Carrell (29) also have explained certain relationships among abnormal human hemoglobins. Evidence for the duplication of this locus in a specific population has recently been presented (30). Kattamis and Lehmann (23, 31) have enlarged this concept to explain the variation in $\alpha$-thalassemia, the presence of $\mathrm{Hb}-\mathrm{H}$ disease, and the occurrence of hydrops fetalis. It is assumed that four genes (two homologous loci) are responsible for $\alpha$-chain synthesis. In $\mathrm{Hb}-\mathrm{H}$ disease, three of the four genes are considered to be "affected." These genes would influence in some abnormal way the synthesis but not the primary sequence of $\alpha$-chains. By implication, because each gene is "affected" in a similar fashion, the augmented expression from "silent" $\alpha$-thalassemia to "classical" $\alpha$-thalassemia, to $\mathrm{Hb}-\mathrm{H}$ disease and to hydrops fetalis is due to an increasing number of affected genes. If the anomaly of family $T$. is related to $\alpha$-thalassemia, the data from this family do not fit the above concepts because the maternal and paternal genes are "affected" differently and because the anomaly is present on the maternal but not the paternal side. If the anomaly in family T. is equivalent to "silent" $\alpha$-thalassemia (one $\alpha$-chain locus affected), the father W. T. with "classical" $\alpha$-thalassemia (two $\alpha$-chain loci affected) should, but does not have components I and II.

The interaction of the abnormality in Family $T$. with $\alpha$-thalassemia deserves attention. $\alpha$-Thalassemia has been observed, for example, in association with $\mathrm{Hb}-\mathrm{G}$ and $\mathrm{Hb}-\mathrm{I}$ which are $\alpha$-chain abnormal hemoglobins. $\mathrm{Hb}-\mathrm{G}-$ $\alpha$-thalassemia has been found in Orientals and is associated with a moderately severe hemolytic anemia and hemoglobin that consists of $\mathrm{Hb}-\mathrm{G}$ or $\alpha_{2}{ }^{\mathrm{G}} \beta_{2}, \mathrm{Hb}-\mathrm{G}_{2}$ or $\alpha_{2}{ }^{\mathrm{G}} \delta_{2}$ and $\mathrm{Hb}-\mathrm{H}$ or $\beta_{4} ; \mathrm{Hb}-\mathrm{A}$ was absent in each case (32). Negro subjects with the $\mathrm{Hb}-\mathrm{I}-\alpha$-thalassemia condition showed a great decrease in the production of $\mathrm{Hb}-\mathrm{A}$; the Hb's $\mathrm{I}$ and $\mathrm{I}_{2}$ accounted for some $70 \%$ (33). Although S. T. with both the anomaly and $\alpha$ thalassemia has 10 times the amount of components I and II as compared to carriers of the anomaly, she is also able to synthesize $70-80 \%$ of normal $\mathrm{Hb}-\mathrm{A}$. In absolute terms, this equals $7.5 \mu \mu \mathrm{g}$ of normal $\alpha$-chains per cell, a quantity which is produced by a single normally functioning $\alpha$-chain structural locus. If, indeed, a normally functioning $\alpha$-chain structural locus is absent in trans to the anomaly (because of the presence of a classical $\alpha$-thalassemia determinant), then this normally functioning $\alpha$-chain structural locus in S. T. must be present in cis to the anomaly of Family $\mathrm{T}$. This conclusion places the anomaly outside current concepts of "silent" or "classical" $\alpha$-thalassemia despite the fact that the interaction of $\alpha$-thalassemia and the 
anomaly results in manifestations of $\mathrm{Hb}-\mathrm{H}$ disease. Because the determinant for the anomaly allows the production not only of $\alpha^{\boldsymbol{\Lambda}}$ but also $\alpha^{\text {Comp. I }}$ and $\alpha^{\text {Comp. II }}$ chains, it may be that a triplicated $\alpha$-locus is present.

\section{ACKNOWLEDGMENTS}

We appreciate greatly the cooperation of all members of the $T$. family in providing the blood samples for this study. This investigation was supported in part by grants HE05168, HE02558, HD48, and FR86 from the National Institutes of Health, United States Public Health Service, and in part by funds from the Southern California Chapter of The Cooley's Anemia Blood and Research Foundation for Children Incorporated.

This is Contribution 4198 from the Division of Chemistry and Chemical Engineering, California Institute of Technology.

Note added in proof: While this paper was in press, Milner, Clegg, and Weatherall (10 April. 1971. Lancet. 729.) have described similar findings in a Chinese family. A1though the chemical evidence is not presented, they report the presence of an elongated $\alpha$-chain in a component that has the characteristics of component II. In further studies of component II, tryptic peptides $\alpha \mathrm{T}-1$ to $\alpha \mathrm{T}-11$ and $\alpha \mathrm{T}-14$ have been found to have the anticipated amino acid compositions but $\alpha \mathrm{T}-12$ and $\alpha \mathrm{T}-13$ in the core have not been studied. In addition, we have observed three tryptic peptides that are not normally present in $\alpha$ - or $\beta$-chains. Two of these have the sequences Trp-Ala-Ser-Gln-Arg and Ala-LeuLeu-Pro-Ser-Leu-His-Arg, but the third has not been obtained in sufficient purity to determine its composition and sequence. The data of Table III are calculated on the assumption that the $\alpha^{\text {comp. II }}$ chain has 141 residues. If they are recalculated on the basis of 172 residues as Milner et al. report, differences in composition between $\alpha$ - and $\alpha^{\text {comp. II }}$ chains become more apparent.

\section{REFERENCES}

1. Rigas, D. A., R. D. Koler, and E. E. Osgood. 1955. New hemoglobin possessing a higher electrophoretic mobility than normal adult hemoglobin. Science (Washington). 121: 372.

2. Gouttas, A., Ph. Fessas, H. Tsevrenis, and E. Xefteri. 1955. Description d'une nouvelle variété d'anémie hémolytique congénitale (Etude hémotologique, électrophorétique et génétique). Sang. 26: 911.

3. Bergren, W. R., and P. Sturgeon. 1958. Hemoglobin H. Some additional findings. Proc. Int. Congr. Int. Soc. Hematol. 7th. Rome. 2: 488.

4. Sturgeon, P., R. T. Jones, W. R. Bergren, and W. A. Schroeder. 1960. Observations on "Bart's" and the "fast" hemoglobins of thalassemia- $\mathrm{H}$ disease. Proc. Int. Congr. Int. Soc. Hematol, 8th. Tokyo. 2: 1041.

5. Jones, R. T., and W. A. Schroeder. 1963. Chemical characterization and subunit hybridization of human hemoglobin $\mathrm{H}$ and associated compounds. Biochemistry. 2: 1357.

6. Fessas, Ph. 1968. The heterogeneity of thalassemia. Proc. Int. Congr. Hematol. 12th. 52.

7. Rucknagel, D. L. 1968. Curr. Diagn. 2: 313.

8. Weatherall, D. J. 1967. The thalassemias. Seminars Hematol. 4: 72.
9. Weatherall, D. J. 1969. The genetics of the thalassaemias. Brit. Med. Bull. 25: 24.

10. Wintrobe, M. M. 1967. Clinical Hematology, Lea \& Febiger, Philadelphia, Pa., 6th edition.

11. Grimes, A. J., A. Meisler, and J. V. Dacie. 1964. Congenital Heinz-body anaemia. Further evidence on the cause of Heinz-body production in red cells. Brit. $J$. Haematol. 10: 281.

12. Efremov, G. D., T. H. J. Huisman, L. L. Smith, J. B. Wilson, J. L. Kitchens, R. N. Wrightstone, and H. R. Adams. 1969. Hemoglobin Richmond, a human hemoglobin which forms asymmetric hybrids with other hemoglobins. J. Biol. Chem. 244: 6105 .

13. Huisman, T. H. J., and A. M. Dozy. 1965. Studies on the heterogeneity of hemoglobin IX. The use of tris (hydroxymethyl) aminomethane- $\mathrm{HCl}$ buffers in the anionexchange chromatography of hemoglobins. J. Chromatogr. 19: 160 .

14. Dozy, A. M., E. F. Kleihauer, and T. H. J. Huisman. 1968. Studies on the heterogeneity of hemoglobin XIII. Chromatography of various human and animal hemoglobin types on DEAE-Sephadex. J. Chromatogr. 32: 723.

15. Schroeder, W. A., T. H. J. Huisman, J. R. Shelton, and J. B. Wilson. 1970. An improved method for the quantitative determination of human fetal hemoglobin. Anal. Biochem. 35: 235.

16. Anson, M. L., and A. E. Mirsky. 1930. Protein coagulation and its reversal; the preparation of insoluble globin, soluble globin, and heme. J. Gen. Physiol. 13: 469.

17. Chernoff, A. I., and N. M. Pettit, Jr. 1964. The amino acid composition of hemoglobin. III. A qualitative method for identifying abnormalities of the polypeptide chains of hemoglobin. Blood. 24: 750.

18. Clegg, J. B., M. A. Naughton, and D. J. Weatherall. 1966. Abnormal human hemoglobins. Separation and characterization of the $\alpha$ and $\beta$ chains by chromatography, and the determination of two new variants, $\mathrm{Hb}$ Chesapeake and Hb J (Bangkok). J. Mol. Biol. 19: 91.

19. Clegg, J. B., M. A. Naughton, and D. J. Weatherall. 1968. Separation of the $\alpha$ - and $\beta$-chains of human haemoglobin. Nature (London). 219: 69.

20. Jones, R. T., and G. Weiss. 1964. Long-path flow cells for automatic amino acid analysis. Anal. Biochem. 9: 377.

21. Weatherall, D. J. 1965. The Thalassaemia Syndromes, Blackwell Scientific Publications Ltd., Oxford. 165.

22. Necheles, T. F., M. Cates, R. G. Sheehan, and H. J. Meyer. 1966. Hemoglobin $\mathrm{H}$ disease. A family study. Blood. 28: 501.

23. Kattamis, C., and H. Lehmann. 1970. The genetical interpretation of haemoglobin $\mathrm{H}$ disease. Hum. Hered. 20: 156.

24. Wasi, P., S. Na-Nakorn, S. Pootrakul, M. Sookanek, P. Disthasongchan, M. Porntrakul, and V. Panich. 1969. Alpha- and beta-thalassemia in Thailand. Ann. N. Y. Acad. Sci. 165: 60 .

25. Wasi, P. 1970. The alpha thalassemia genes. J. Med. Ass. Thailand. 53: 677.

26. Dance, N., E. R. Huehns, and G. H. Beaven. 1963. The abnormal haemoglobins in haemoglobin-H disease. Biochem. J. $87: 240$.

27. Wasi, P., S. M. Na-Nakorn, and A. Suingdumrong. 
1964. Haemoglobin $\mathrm{H}$ disease in Thailand: a genetical study. Nature (London). 204: 907.

28. Koler, R. D., and D. A. Rigas. 1961. Genetics of haemoglobin H. Ann. Hum. Genet. 25: 95.

29. Lehmann, H., and R. W. Carrell. 1968. Differences between $\alpha$ - and $\beta$-chain mutants of human haemoglobin and between $\alpha$ - and $\beta$-thalassaemia. Possible duplication of the $\alpha$-chain gene. Brit. Med. J. 4: 748.

30. Brimhall, B., S. Hollán, R. T. Jones, R. D. Koler, Z. Stocklen, and J. G. Szelényi. 1970. Multiple alpha-chain loci for human hemoglobin. Clin. Res. 18: 184.
31. Kattamis, C., and H. Lehmann. 1970. Duplication of alpha-thalassaemia gene in three Greek families with haemoglolin $\mathrm{H}$ disease. Lancet. 2: 635.

32. Dormandy, K. M., S. P. Lock, and H. Lehmann. 1961. Haemoglobin Q-alpha-thalassaemia. Brit. Med. J. 1: 1582.

33. Atwater, J., I. R. Schwartz, A. J. Erslev, T. L. Montgomery, and L. M. Tocantins. 1960. Sickling of erythrocytes in a patient with thalassemia-hemoglobin-I disease. N. Engl. J. Med. 263: 1215. 